\title{
Perilaku Sosial PT. PerkebunanNusantara V (Persero) Sebagai Bentuk Pertanggung Jawaban Sosial Perusahaan Terhadap Lingkungan Sekitar
}

\author{
Oleh \\ Noviyanti Zaitun Kaaro \\ LintjeKalangi
}

\begin{abstract}
ABSTRAK
Perusahaan berperan untuk mendorong pertumbuhan ekonomi yang sehat dengan mempertimbangkan faktor lingkungan hidup. Saat ini dunia usaha tidak hanya memperhatikan keuntungan yang didapatkan, namun juga harus memperhitungkan aspek sosial, dan lingkungan. Ketiga elemen inilah yang kemudian bersinergi membentuk konsep pembangunan berkelanjutan.

Analisis ini dilakukan pada PT Perkebunan Nusantara V (Persero). Perusahaan tersebut bergerak dalam bidang usaha perkebunan, agro wisata dan agro bisnis. Tujuan penelitian ini adalah mengetahui perilaku sosial perusahaan terhadap lingkungan sekitarnya. Metode analisis data yang digunakan adalah metode deskriptif komparatif, yaitu dengan menggambarkan dan menguraikan data mengenai Corporate Social Responsibilityyang terdapat pada PT Perkebunan Nusantara V (Persero). Kemudian data-data tersebut dibandingkan dengan data-datadi masa lalu.

Hasil analisis menunjukkan bahwa PT. Perkebunan Nusantara V (Persero) telah melakukan tanggung jawab sosial perusahaan terhadap lingkungan sekitarnya yang terkait dengan masyarakat, lingkungan dan sumber daya manusia walaupun belum secara proporsional.
\end{abstract}

Kata Kunci: Pertanggung Jawaban Sosial Perusahaan

\section{ABSTRAC}

Company'srole is toencouragehealthy economic growth with environmental factors into account. Currently the businessis not only concerned with the gains, but also should take into account the social aspects, and the environment. The third elementis then synergize to form the concept of sustainable development

The analysis was conducted on Plantations PT. NusantaraV (Persero). The companyis engaged infarming, agro-tourism and agro-business. The purposeof this study was to determine the company's social behavior to the surrounding environment. Data analysis method used is descriptive comparative method, by describing and outlining data on Corporate Social Responsibility on PT Nusantara Plantation $V$ (Persero). Then these data are compared with datain the past.

The analysis showed that PT. PTPN V (Persero) has made corporate social responsibility towards the environment associated with the community, the environment and human resources, although not proportionally.

Keyword: Corporate Social Responsibility 


\section{PENDAHULUAN}

\subsection{ALASAN PEMILIHAN JUDUL}

Akuntansi pertanggungjawaban sosial (Social Responsibility Accounting) didefinisikan sebagai proses seleksi variabel-variabel kinerja sosial tingkat perusahaan, ukuran dan prosedur pengukuran, yang secara sistematis mengembangkan informasi yang bermanfaat untuk mengevaluasi kinerja sosial perusahaan dan mengkomunikasikan informasi tersebut kepada kelompok sosial yang tertarik, baik di dalam maupun di luar perusahaan. Akuntansi pertanggungjawaban sosial dapat memberikan informasi mengenai sejauh mana organisasi atau perusahaan memberikan kontribusi positif maupun negatif terhadap kualitas hidup manusia dan lingkungannya [Belkaoui dalam Komar (2004)].

Melihat pentingnya pelaksanaan Corporate Social Responsibility dalam membantu perusahaan menciptakan citra positifnya maka perusahaan seharusnya melihat Corporate Social Responsibility bukan sebagai sentra biaya (cost center) melainkan sebagai sentra laba (profit center) di masa mendatang. Logikanya sederhana, jika Corporate Social Responsibility diabaikan kemudian terjadi insiden. Maka biaya yang dikeluarkan untuk biaya recovery bisa jadi lebih besar dibandingkan biaya yang ingin dihemat melalui peniadaan Corporate Social Responsibility itu sendiri. Hal ini belum termasuk pada resiko non-finansial yang berupa memburuknya citra perusahaan di mata publiknya (Wibisono, 2007).

PT. Perkebunan Nusantara V (Persero) dalam menjalankan operasinya tidak semata-mata bertujuan memenuhi kepentingan pemegang saham (shareholders), namun juga memperhatikan keselarasan dengan pihak-pihak lain yang berkepentingan (stakeholders). Manajemen berkeyakinan bahwa eksistensi dan operasi perusahaan harus memberi manfaat bagi stakeholders-nya.

Beberapa bentuk tanggung jawab sosial yang dilakukan oleh PT. Perkebunan Nusantara V (Persero) yaitu, perusahaan menetapkan indikator-indikator mutu atas produk yang diserahkan kepada pembeli, menyelenggarakan program pensiun manfaat pasti untuk seluruh karyawan tetap melalui Dana Pensiun Perkebunan (Dapenbun), pembinaan karyawan dilaksanakan secara terstruktur melalui mekanisme reward and punishment serta mutasi dan promosi. Sedangkan untuk pengembangan karyawan, perusahaan memberikan kesempatan untuk mengikuti program pendidikan, baik yang diselenggarakan secara internal (in house training) maupun yang diselenggarakan oleh lembagalembaga pendidikan. Selain itu perusahaan juga telah menyalurkan dana bina lingkungan kepada masyarakat sekitar yang meliputi sektor pendidikan, sektor kerohanian, sektor kesehatan, sektor olahraga, sektor kesenian serta bantuan untuk bencana alam dan infrastruktur. Selain itu PT. Perkebunan Nusantara V (Persero) juga memberikan pembinaan manajemen dan bantuan teknis kepada petani plasma sekitar kebun. Perusahaan mengupayakan teknologi yang lebih bersih dan ramah lingkungan pada setiap kegiatan produksi.

\subsection{Perumusan Masalah}

Berkaitan dengan uraian diatas dimana PT. Perkebunan Nusantara V (Persero) merupakan salah satu perusahaan dari sekian banyak perusahaan BUMN yang telah menjalankan Corporate Social Responsibility (CSR) . Maka penulis merumuskan beberapa permasalahan antara lain :

1. Bagaimanakah bentuk pertanggungjawaban sosial perusahaan dalam melaksanakan aktivitasaktivitasnya terhadap lingkungan sekitarnya?

2. Bagaimanakah bentuk laporan akuntansi pertanggungjawaban sosial pada PT. Perkebunan Nusantara V (Persero)?

3. Apakah terdapat keterkaitan antara tanggung jawab sosial (CSR) dengan penjualan bersih perusahaan.

\subsection{Tujuan Analisis Kasus}

Tujuan dari penelitian ini adalah untuk memberikan kesimpulan yang dapat diterima secara umum mengenai :

1. Mengetahui bentuk-bentuk pertanggungjawaban sosial perusahaan terhadap alam dan lingkungan sekitar dalam melaksanakan aktivitas operasionalnya. 
2. Mengetahui bentuk laporan akuntansi pertanggungjawaban sosial PT. Perkebunan Nusantara V (Persero), elemen-elemen yang terkandung dalam laporan biaya sosial tersebut serta,

3. Mengetahui keterkaitan antara tanggungjawab sosial perusahaan dengan tingkat penjualan perusahaan.

\subsection{Metode Analisis Kasus}

Penulis menggunakan metode analisis Deskriptif dimana Data kualitatif dan kuantitatif yang telah diperoleh melalui prosedur pengumpulan data, selanjutnya dilakukan penyesuaian dan pengolahan data, kemudian dianalisis sesuai dengan tujuan penelitian dan dibandingkan dengan teoriteori yang dipakai dalam penulisan penelitian ini sehingga dapat ditarik kesimpulan apakah perusahaan dalam hal ini PT. Perkebunan Nusantara V (Persero) telah melaksanakan tanggung jawab sosial perusahaan kepada masyarakat sekitar dan telah mengungkapkannya secara benar dalam laporan keuangannya..

Secara garis besar teknik analisis yang dilakukan antara lain sebagai berikut:

1. Merumuskan masalah penelitian, yaitu mengenai peranan perilaku sosial pada PT. Perkebunan Nusantara V (Persero). sebagai bentuk pertanggungjawaban sosial perusahaan (Corporate Social Responsibility) terhadap lingkungan sekitarnya.

2. Melakukan telaah terhadap teori-teori yang berkaitan dengan masalah yang diteliti.

3. Merancang metodologi penelitian.

4. Mengidentifikasi kegiatan utama PT. Perkebunan Nusantara V (Persero).

5. Berdasarkan hasil analisis diambil kesimpulan dan diberikan saran-saran yang perlu terhadap hasil penelitian.

\section{LANDASAN TEORITIS}

\subsection{AKUNTANSI PERTANGGUNGJAWABAN SOSIAL}

Corporate Social Responsibility adalah komitmen perusahaan untuk memberikan kontribusi jangka panjang terhadap satu issue tertentu di masyarakat atau lingkungan untuk dapat menciptakan lingkungan yang lebih baik. Kontribusi dari perusahaan ini bisa berupa banyak hal, misalnya : bantuan dana, bantuan tenaga ahli dari perusahaan, bantuan berupa barang, dll. Di sini perlu dibedakan antara program Corporate Social Responsibility dengan kegiatan charity. Kegiatan charity hanya berlangsung sekali atau sementara waktu dan biasanya justru menimbulkan ketergantungan publik terhadap perusahaan. Sementara, program Corporate Social Responsibility merupakan program yang berkelanjutan dan bertujuan untuk menciptakan kemandirian publik ("Paradigma Baru CSR", Oktober 2006).

Pertanggungjawaban Sosial Perusahaan atau Corporate Social Resposibility (CSR) adalah mekanisme bagi suatu organisasi untuk secara sukarela mengintegrasikan perhatian terhadap lingkungan dan sosial ke dalam operasinya dan interaksinya dengan stakeholders, yang melebihi tanggung jawab organisasi di bidang hukum (Darwin, 2004). Pertanggungjawaban sosial perusahaan diungkapkan di dalam laporan yang disebut Sustainability Reporting. Sustainability Reporting adalah pelaporan mengenai kebijakan ekonomi, lingkungan dan sosial, pengaruh dan kinerja organisasi dan produknya di dalam konteks pembangunan berkelanjutan (sustainable development). Sustainability Reporting meliputi pelaporan mengenai ekonomi, lingkungan dan pengaruh sosial terhadap kinerja organisasi (ACCA, 2004). Sustainability report harus menjadi dokumen strategik yang berlevel tinggi yang menempatkan isu, tantangan dan peluang Sustainability Development yang membawanya menuju kepada core business dan sektor industrinya.

Darwin (2004) mengatakan bahwa Corporate Sustainability Reporting terbagi menjadi 3 kategori yaitu kinerja ekonomi, kinerja lingkungan dan kinerja sosial seperti yang tampak dalam tabel 2.1 berikut ini: 
Tabel 2.1 Kategori dalam Corporate Sustainability Reporting

\begin{tabular}{|c|c|}
\hline Kategori & Aspek \\
\hline \multicolumn{2}{|r|}{ Kinerja Ekonomi } \\
\hline $\begin{array}{l}\text { Pengaruh } \\
\text { ekonomi secara } \\
\text { langsung }\end{array}$ & $\begin{array}{l}\text { Pelanggan, pemasok, karyawan, penyedia modal dan sektor } \\
\text { publik }\end{array}$ \\
\hline \multicolumn{2}{|r|}{ Kinerja Lingkungan } \\
\hline $\begin{array}{l}\text { Hal-hal yang } \\
\text { terkait dengan } \\
\text { lingkungan }\end{array}$ & $\begin{array}{l}\text { Bahan baku, energi, air, Keanekaragaman hayati (biodiversity), } \\
\text { emisi, sungai, dan sampah, pemasok, produk dan jasa, } \\
\text { pelaksanaan, dan angkutan }\end{array}$ \\
\hline \multicolumn{2}{|r|}{ Kinerja Sosial } \\
\hline Praktik Kerja & $\begin{array}{l}\text { Keamanan dan keselamatan tenaga kerja, pendidikan dan } \\
\text { training, kesempatan kerja }\end{array}$ \\
\hline Hak manusia & $\begin{array}{l}\text { Strategi dan manajemen, non diskriminasi, kebebasan berserikat } \\
\text { dan berkumpul, tenaga kerja di bawah umur, kedisiplinan, } \\
\text { keamanan, dll. }\end{array}$ \\
\hline Sosial & Komunitas, korupsi, kompetisi dan penetapan harga \\
\hline $\begin{array}{l}\text { Tanggung jawab } \\
\text { terhadap produk }\end{array}$ & $\begin{array}{l}\text { Kesehatan dan keamanan pelanggan, iklan yang peduli terhadap } \\
\text { hak pribadi. }\end{array}$ \\
\hline
\end{tabular}

Sumber: Darwin (2004)

Meskipun ada beberapa perbedaan dalam definisi tentang akuntansi pertanggungjawaban sosial, pada prinsipnya memiliki persamaan dalam karakteristiknya seperti yang ditulis oleh Lee yaitu :

1. Menilai dampak sosial dari kegiatan-kegiatan perusahaan.

2. Mengukur efektifitas dari program perusahaan yang bersifat sosial.

3. Melaporkan sampai seberapa jauh perusahaan memenuhi tanggung jawab sosialnya.

4. Sistem informasi internal dan eksternal yang memungkinkan penilaian menyeluruh terhadap sumber daya.

Menurut Glautier dan Underdown ada tiga pendekatan yang dapat digunakan untuk pedoman pengukuran dalam pelaporan akuntansi pertanggungjawaban sosial, yaitu :

1. Pendekatan Deskriptif ( the descriptive approach)

2. Pendekatan biaya yang dikeluarkan (the cost of outlay approach)

3. Pendekatan biaya manfaat (the cost benefit approach)

Menurut Estes seperti yang dikutip oleh Sonhaji (2003 : 9) menemukan adanya bermacammacam praktek pelaporan akuntansi sosial untuk pihak luar. Tiga tingkat cara pelaporan social responsibility accounting lembaga masyarakat, diantaranya adalah :

1. Praktek yang sederhana

Laporan ini hanya terdiri dari uraian yang tidak disertai dengan data kuantitatif,baik satuan uang maupun satuan yang lainnya.

2. Praktek yang lebih maju

Selain yang ditunjukkan dalam metode yang sederhana seperti di atas, juga menggunakan data kuantitatif untuk menunjukkan apa yang sudah dicapai perusahaan

3. Praktek yang paling maju.

Bentuk laporan yang selain berupa uraian data kualitatif dan kuantitatif perusahaan juga menyusun laporannya dalam bentuk neraca.

Menurut Glautier dan Underdown, diterangkan ada tiga tahapan perkembangan filosofi manajemen yang menyangkut tanggung jawab, yatu :

1. Tahapan pandangan manajemen klasik.

2. Tahapan pandangan Manajemen Pertengahan. 


\section{Tahapan pandangan Manajemen Modern.}

Jadi perusahaan dalam melaksanakan kegiatan operasinya secara langsung maupun tidak langsung harus mau berinteraksi dengan lingkungan sosialnya. Dikatakan Usmansyah bahwa sumbersumber ekonomi yang digunakan oleh perusahaan semuanya berasal dari masyarakat. Oleh karenanya perusahaan seharusnya memberikan laporan kepada masyarakat umum tentang sumber-sumber ekonomi yang digunakan, hasil-hasil yang telah dicapai dan semua yang diakibatkan atas penggunaan sumber-sumber ekonomi tersebut, baik yang bersifat positif maupun negatif, dan hal tersebut sesuai dengan perkembangan yang terbaru dalam pandangan manajemen.

\section{GAMBARAN UMUM PERUSAHAAN}

PT Perkebunan (PTP) adalah BUMN yang modal dasarnya berasal dari Pemerintah RI, namun operasionalnya bertumpu pada laba yang diperoleh dan pinjaman dana / kredit dari perbankan. Pada tahun 1979, pemerintah melalui Menteri Pertanian berdasarkan Surat Keputusan Menteri Pertanian Nomor 178/Kpts/Um/3/1979 tanggal 17 Maret 1979 tentang "Daerah Pengembangan PN/PT Perkebunan" menugasi beberapa PTP di wilayah Sumatera Utara, diantaranya PTP II di Tanjung Morawa, PTP IV Gunung Pamela, Tebing Tinggi dan PTP V Sei Karang untuk membuka areal perkebunan di wilayah Riau dalam rangka meningkatkan hasil ekspor non migas dengan meningkatkan produksi perkebunan melalui perluasan areal baru dan program percepatan sub sektor perkebunan untuk peningkatan devisa. Selain itu, berdasarkan Surat Menteri Pertanian Nomor 918/Mentan/XI/1981 tanggal 25 Nopember 1981 tentang Penugasan, maka PTP diantaranya PTP II dan PTP IV ditugasi sebagai pelaksana pengembangan program Perkebunan Inti Rakyat (PIR) maupun PIR-Trans. Kebun - kebun pengembangan eks PTP II, PTP IV dan PTP V inilah yang menjadi cikalbakal PTPN V sekarang ini.

Kemudian, berdasarkan Peraturan Pemerintah Republik Indonesia Nomor 10 Tahun 1996 tanggal 14 Februari 1996 tentang "Penyetoran Modal Negara Republik Indonesia untuk Pendirian Perusahaan Perseroan (Persero) PT Perkebunan Nusantara V", Pemerintah memandang perlu untuk mendirikan Perusahaan Perseroan dan memutuskan Penyertaan Modal Negara Republik Indonesia untuk pendirian Persero baru, yaitu PT Perkebunan Nusantara V (Persero) atau PTPN V. Modal PTPN V yang ditempatkan dan disetor adalah kekayaan Negara yang berasal (terbentuk) dari proyek-royek pengembangan tahun 1979 di Propinsi Riau yang ditugaskan Pemerintah Pusat kepada eks PTP II, PTP IV dan PTP V.

\section{ANALISIS DAN EVALUASI}

\subsection{Identifikasi Aktivitas Sosial Perusahaan}

Kemitraan dengan petani plasma adalah komitmen stratejik yang telah dijalankan Perusahaan sejak awal. Komitmen tersebut terefleksi dalam desain fasilitas produksi (pabrik) milik Perusahaan yang mengakomodasi hasil panen dari lahan milik petani plasma. Sejak berdirinya Perusahaan, Pemerintah telah memberikan penugasan untuk tetap melanjutkan kemitraan dengan petani plasma yang sebelumnya telah dibangun oleh cikal bakal Perusahaan, yaitu ex-PTP II, IV dan V. Proyek PIR yang ditangani oleh Perusahaan adalah PIR BUN dan PIR Trans, dengan komposisi luas areal dan jumlah peserta seperti yang ada di tabel 4.1 dan tabel 4.2 berikut:

\section{Tabel 4.1}

Kemitraan dengan Komposisi Luas Areal

\begin{tabular}{|c|l|r|}
\hline No & \multicolumn{1}{|c|}{ Uraian } & $\begin{array}{l}\text { Luas Areal } \\
\text { (Ha) }\end{array}$ \\
\hline 1 & Luas areal Kebun Plasma Perusahaan adalah sebagai berikut: & - \\
\hline & a. Tanaman Belum Menghasilkan (TBM) & $74.526,00$ \\
\hline & b. Tanaman Menghasilkan (TM ) & $14.292,75$ \\
\hline & c. Luas Areal Tanaman Pangan & \multicolumn{1}{|c|}{. } \\
\hline
\end{tabular}




\begin{tabular}{|c|c|c|}
\hline & d. Lahan Pekarangan & $9.435,50$ \\
\hline & Total Areal Luas Kebun Plasma (termasuk areal puso $37 \mathrm{Ha}$ ) & $98.254,25$ \\
\hline \multirow[t]{10}{*}{2} & $\begin{array}{l}\text { Luas areal lahan pangan dan pekarangan di proyek PIR Perusahaan } \\
\text { adalah sebagai berikut: }\end{array}$ & \\
\hline & a. PIR BUN & \\
\hline & - Lahan Tanaman Pangan & $14.292,75$ \\
\hline & - Lahan Pekarangan & $7.817,75$ \\
\hline & Jumlah / Total & $22.110,50$ \\
\hline & b. PIR TRANS & \\
\hline & - Lahan Tanaman Pangan & 0,00 \\
\hline & - Lahan Pekarangan & $1.617,75$ \\
\hline & Jumlah / Total & $1.617,75$ \\
\hline & Jumlah $\mathrm{a}+\mathrm{b}$ & $23.728,25$ \\
\hline
\end{tabular}

Tabel 4.2

Kemitraan dengan Komposisi Luas Areal dan Jumlah Petani

\begin{tabular}{|c|l|l|r|}
\hline No & \multicolumn{1}{|c|}{ Uraian } & $\begin{array}{l}\text { Luas } \\
\text { Areal } \\
\text { (Ha) }\end{array}$ & $\begin{array}{l}\text { Jumlah } \\
\text { Petani } \\
\text { (KK) }\end{array}$ \\
\hline 3 & $\begin{array}{l}\text { Luas areal Tanaman Pokok dan jumlah petani menurut jenis } \\
\text { komoditi adalah sebagai berikut: }\end{array}$ & \\
\hline & a. Tanaman Kelapa Sawit & 56.665 & 28.341 \\
\hline & b. Tanaman Karet & 17.861 & 9.702 \\
\hline & Total Luas Areal Tanaman & $\mathbf{7 4 . 5 2 6}$ & $\mathbf{3 8 . 0 4 3}$ \\
\hline 4 & $\begin{array}{l}\text { Luas areal Tanaman Pokok dan jumlah petani menurut jenis proyek } \\
\text { adalah sebagai berikut: }\end{array}$ & & \\
\hline & a. Proyek PIR BUN & 62.526 & 32.043 \\
\hline & b. Proyek PIR TRANS & 12.000 & 6.000 \\
\hline & Total Luas areal tanaman & $\mathbf{7 4 . 5 2 6}$ & $\mathbf{3 8 . 0 4 3}$ \\
\hline
\end{tabular}

*KK : Kepala Keluarga

Kemitraan Perusahaan terhadap para petani tersebut meliputi aspek pemasaran hasil produksi, fasilitator pembiayaan pembangunan kebun, pembinaan teknis, fasilitator perencanaan dana peremajaan Iuran Dana Peremajaan Tanaman Perkebunan (IDAPERTABUN) dan sebagainya.

Selain perkebunan masyarakat berskema PIR-BUN dan PIR-Trans, Perusahaan juga membangun perkebunan masyarakat dengan skema KKPA, yaitu perkebunan yang didanai dengan fasilitas Kredit Koperasi Primer untuk Anggotanya (KKPA). Perkebunan pola KKPA ini dibangun di empat kabupaten di Riau, yaitu di Kabupaten Kampar, Indragiri Hulu (Inhu), Rokan Hulu dan Kuantan Singingi (Kuansing). Komoditas yang dibudidayakan dalam perkebunan KKPA ini adalah tanaman kelapa sawit. Saat ini perkebunan KKPA ini telah dilaksanakan dalam tiga tahap, dan masih akan dilanjutkan dalam tahap-tahap berikutnya.

Pelaksanaan perkebunan KKPA tersebut adalah sebagai berikut:

Tahap I seluas 1.200 hektar, dimulai pada tahun 2001, diikuti oleh 10 koperasi unit desa (KUD) yang tersebar di Kabupaten : Kampar, Indragiri Hulu (Inhu) dan Rokan Hulu (Rohul). Hingga akhir 2007, perkebunan ini telah memasuki masa Tanaman Menghasilkan (TM). 
Tahap II seluas 3.000 hektar, dimulai pada tahun 2003, diikuti oleh sembilan KUD yang tersebar di Kabupaten : Kampar, Inhu dan Rohul. Hingga akhir 2007, perkebunan ini telah memasuki masa Tanaman Belum Menghasilkan tahun ketiga (TM-III).

Tahap III seluas 3.000 hektar, dimulai pada tahun 2007, diikuti oleh delapan KUD yang tersebar di Kabupaten : Kampar, Inhu, Rohul dan Kuansing.

Perusahaan juga mengelola perkebunan masyarakat melalui kerjasama dengan Pemerintah Kabupaten (Pemkab) Siak. Pembangunan kebun dilaksanakan oleh Perusahaan dengan pembiayaan sepenuhnya berasal dari Anggaran Penerimaan dan Belanja Daerah (APBD) Pemkab Siak. Komoditas yang dibudidayakan dalam perkebunan masyarakat Siak ini adalah tanaman kelapa sawit. Hingga saat ini, pembangunan kebun telah dilaksanakan dalam dua tahap.

Pembangunan kebun tahap I dilaksanakan di dua kecamatan yang meliputi tujuh desa dengan luas areal 3.500 hektar. Hingga akhir 2007, status tanaman masih dalam tahap investasi, yaitu masa TBM-III, namun kegiatan panen telah dapat dilakukan sejak bulan Nopember 2006. Pembangunan kebun tahap II yang direncanakan dibangun pada areal seluas 5.182 Ha telah dimulai sejak tahun 2005, di lima kecamatan yang meliputi 11 desa. Realisasi pembangunan kebun hingga akhir 2007 meliputi 2.038 hektar berupa TBM I, 1.000 hektar dalam tahap TBM II dan 700 hektar masih dalam tahap pembersihan areal tanaman dan persiapan bibit.

Kemitraan dengan Pemkab Siak ini akan ditingkatkan dengan rencana pembentukan perusahaan patungan, dengan melibatkan Institut Pertanian Bogor (IPB), dalam bentuk pengembangan perkebunan budidaya tanaman kelapa sawit dan pengolahan hasil-hasil produksinya. Perusahaan juga sedang menjajaki kemungkinan kerjasama pengembangan kebun dengan pemerintah daerah lainnya.

\section{Program Kemitraan}

Program Kemitraan yang sebelumnya bernama Program Pembinaan Usaha Kecil dan Koperasi (PUKK) merupakan wujud pertanggungjawaban sosial Perusahaan yang didanai dari alokasi hasil laba Perusahaan. Program ini berbentuk pemberian pinjaman modal kerja kepada sektor usaha kecil, mikro dan koperasi dengan imbal jasa (bunga) yang terjangkau. Pengembalian modal kerja tersebut dan hasil pengembangannya dialokasikan kembali untuk membantu usaha kecil, mikro dan koperasi lainnya.

Sepanjang tahun 2007, Perusahaan menyalurkan bantuan pinjaman modal kerja sebesar Rp. 3.268.500.000,- atau 92,07\% dari rencana sebesar Rp. 3.550.000.000,- untuk 165 unit mitra binaan di Kabupaten Kampar, Kabupaten Siak, serta Kabupaten Indragiri Hulu dan untuk penyaluran hibah sebesar Rp. 339.750.000,- atau 47,85\% dari rencana sebesar Rp. 710.000.000,- untuk membiayai kegiatan pembinaan/pelatihan, studi banding, pameran/promosi mitra binaan.

Sejak program kemitraan ini digulirkan, perputaran dana yang dipergunakan untuk membantu usaha kecil, mikro dan koperasi telah mencapai Rp 23.929.729.194. Tercatat 1.463 unit mitra binaan, yang bergerak di bidang usaha industri, perdagangan, pertanian, perkebunan, perikanan dan jasa, yang telah menikmati modal kerja bergulir tersebut.

Aset Program Kemitraan merupakan aset yang terpisah dari Perusahaan dan tidak dikonsolidasikan dalam aset Perusahaan. Hingga akhir 2007, aset Program Kemitraan telah mencapai Rp 14.448.425.343, termasuk di dalamnya piutang modal kerja yang disuntikkan ke para mitra sebesar Rp 11.246.217.983 yang dikelola oleh Perusahaan dan dana kemitraan yang dikelola oleh Bank Mandiri sebesar Rp 1.066.000.000. Nilai realisasi aset tersebut melampaui anggaran 2007 yang direncanakan sebesar Rp 13.636.722.827 dan lebih lebih tinggi dari aset tahun 2006 yang tercatat $\mathrm{Rp}$ 13.650.357.675.

\section{Konsumen dan Pemasok}

Perusahaan tidak menyelenggarakan proses penjualan produk melalui hubungan langsung dengan pembeli. Transaksi penjualan dilaksanakan melalui lembaga bersama bentukan PTPN I-XIV, yaitu Kantor Pemasaran Bersama (KPB) PTPN I-XIV melalui proses tender. Namun Perusahaan senantiasa memelihara kualitas produk yang diserahkan kepada pembeli. Perusahaan menetapkan 
batasan indikator-indikator mutu atas produk yang diserahkan kepada pembeli, antara lain kadar asam lemak bebas, kadar air, kadar kotoran dan sebagainya.

Pemasok utama Perusahaan adalah pemasok Tandan Buah Segar (TBS) Kelapa Sawit. Pemasok TBS umumnya adalah petani plasma binaan Perusahaan. Tata cara pembelian TBS dari petani mempergunakan rumusan harga TBS yang diatur oleh Pemerintah. Dalam kondisi harga pasar TBS lebih tinggi daripada harga yang dihitung berdasarkan formulasi, maka Perusahaan bersedia membeli TBS dengan harga yang lebih premium.

Pemasok lain adalah pihak-pihak penyedia kebutuhan yang diperlukan untuk operasionalisasi produksi dan perkantoran Perusahaan. Untuk memberikan kesempatan

yang sama bagi para pemasok, Perusahaan menerapkan sistem pengadaan barang dan jasa yang didasarkan pada prinsip-prinsip tata kelola perusahaan yang baik.

\subsection{Akuntansi pertanggungjawaban sosial sebagai bentuk tanggung jawab sosial perusahaan terhadap lingkungannya.}

Pada bagian pendahuluan dan tinjauan pustaka dijelaskan bahwa belum terdapat bentuk baku pelaporan pelaksanaan tanggung jawab sosial perusahaan, akan tetapi laporan hasil pertanggungjawaban sosial tersebut pada dasarnya sesuai dengan tujuan untuk memberikan informasi mengenai tanggung jawab sosial yang telah dilaksanakan perusahaan dengan memberikan sumbangan atau kontribusi kepada berbagai pihak yang berperan dalam perusahaan. Baik itu pihak internal yaitu manajemen beserta karyawannya maupun pihak eksternal yaitu masyarakat sekitar.

Salah satu pendekatan yang digunakan dalam penerapan akuntansi pertanggungjawaban sosial adalah pendekatan biaya yang dikeluarkan, yang menggambarkan semua pengeluaran dalam satuan uang untuk setiap kegiatan sosial yang telah dilakukan perusahaan. Pendekatan ini menyajikan daftar pengeluaran dari masing-masing aktifitas sosial perusahaan yang diukur dalam satuan uang. Pendekatan ini dapat menggambarkan comparability, yaitu hasil satu tahun dapat dibandingkan dengan tahun lainnya, dalam hal-hal yang berhubungan dengan komitmen keuangan untuk kegiatan sosial. Hal ini dapat dilihat dalam laporan biaya sosial pada tabel 4.5 , dimana perusahaan mengeluarkan biaya sosial untuk periode tahun 2003 sampai dengan tahun 2007.

Kontribusi kepada masyarakat menggambarkan peran aktif perusahaan dalam berinteraksi dengan masyarakat sekitar baik yang bersifat produktif maupun kegiatan sosial. Kontribusi terhadap lingkungan hidup merupakan partisipasi perusahaan dalam merawat dan memperbaiki kondisi lingkungan hidup. Kontribusi terhadap sumber daya manusia merupakan upaya perusahaan untuk meningkatkan kesejahteraan karyawannya dengan harapan dapat meningkatkan kinerja mereka. Karena dengan meningkatnya kinerja karyawan maka produksi perusahaan dapat meningkat dan akhirnya laba perusahaan menjadi meningkat pula.

Tabel 4.6

Prosentase Kenaikan/(Penurunan) Total Biaya Sosial (Periode 2003 s/d 2007)

\begin{tabular}{|l|r|r|r|}
\hline Periode & Total Biaya Sosial & Proporsi & $\begin{array}{l}\text { Prosentase } \\
\text { Kenaikan / } \\
\text { (Penurunan) }\end{array}$ \\
\hline 31-Des-03 & 2.822 .916 .000 & 30,28 & \\
\hline 31-Des-04 & 1.982 .701 .000 & 21,27 & $(9,01)$ \\
\hline 31 -Des-05 & 1.423 .807 .000 & 15,27 & $(5,99)$ \\
\hline 31-Des-06 & 1.899 .793 .000 & 20,38 & 5,11 \\
\hline 31-Des-07 & 1.194 .112 .000 & 12,81 & $(7,57)$ \\
\hline Total 2003 - 2007 & $\mathbf{9 . 3 2 3 . 3 2 9 . 0 0 0}$ & $\mathbf{1 0 0 , 0 0}$ & \\
\hline
\end{tabular}

Sumber: Data Internal Perusahaan yang telah diolah 
Dari tabel 4.6 dapat dilihat proporsi biaya sosial yang dialokasikan oleh PT. Perkebunan Nusantara V (Persero) bervariasi dimana pada tahun 2003 total biaya sosial yang dialokasikan sebesar Rp 2.822.916.000 atau sebesar 30,28\%, kemudian di tahun 2004 mulai mengalami penurunan sebesar $9,01 \%$ dibandingkan dengan total biaya tahun 2003, total biaya sosial tahun 2004 hanya sebesar Rp 1.982.701.000 atau 21,27\%. Pada tahun 2005 alokasi biaya sosial lebih rendah daripada tahun 2003 dan tahun 2004, yaitu hanya sebesar Rp 1.423.807.000 atau 15,27\%, dibandingkan dengan tahun 2004, alokasi biaya tahun 2005 mengalami penurunan sebesar 5,99\%. Dan di tahun 2006 alokasi biaya sosial mengalami kenaikan sebesar 5,11\% dibandingkan alokasi biaya sosial tahun 2005 yaitu menjadi sebesar Rp 1.899.793.000. Namun pada akhir tahun 2007, alokasi biaya sosial kembali mengalami penurunan dan merupakan alokasi biaya sosial terendah dalam kurun waktu 5 tahun terakhir (periode 2003 sampai dengan 2007), yaitu hanya sebesar $\mathrm{Rp} 1.194 .112 .000$ atau sebesar 12,81\%. Bila dibandingkan dengan tahun 2006, maka alokasi biaya sosial tahun 2007 mengalami penurunan sebesar 7,57\%. Nilai alokasi biaya sosial yang bervariasi tersebut terjadi karena tidak adanya aturan baku yang ditetapkan oleh Pemerintah mengenai jumlah biaya sosial yang harus diberikan oleh perusahaan. Untuk itu diperlukan suatu informasi mengenai hubungan antara besarnya penurunan/kenaikan penjualan bersih dengan biaya sosial. Hal ini juga dapat diketahui dari perbandingan biaya sosial terhadap penjualan bersih dari tahun 2003 dan tahun 2007 yang tercantum dalam tabel 4.7 berikut :

\section{Tabel 4.7}

\section{Proporsi Biaya Sosial terhadap Penjualan Bersih}

(Dalam Ribuan Rupiah)

\begin{tabular}{|l|r|r|r|r|r|}
\hline & & & & & \\
\multicolumn{1}{|c|}{ Uraian } & \multicolumn{1}{c|}{2003} & \multicolumn{1}{c|}{2004} & \multicolumn{1}{c|}{2005} & \multicolumn{1}{c|}{2006} & \multicolumn{1}{c|}{2007} \\
\hline Penjualan Bersih & 1.481 .936 .000 & 1.725 .737 .000 & 1.558 .800 .000 & 1.523 .991 .000 & 2.413 .293 .000 \\
\hline Biaya Sosial & 2.822 .916 & 1.982 .701 & 1.423 .807 & 1.899 .793 & 1.194 .112 \\
\hline Proporsi (\%) & $\mathbf{0 , 1 9}$ & $\mathbf{0 , 1 1}$ & $\mathbf{0 , 0 9}$ & $\mathbf{0 , 1 2}$ & $\mathbf{0 , 0 5}$ \\
\hline
\end{tabular}

Sumber: Data Internal Perusahaan yang telah diolah

Dari tabel 4.7 tampak bahwa pada tahun 2003 penjualan bersih perusahaan sebesar Rp. 1.481.936.000.000 sedangkan biaya sosial yang dialokasikan adalah sebesar Rp. 2.822.916000 atau $0,19 \%$ dari total penjualan bersih. Pada tahun 2004, penjualan bersih sebesar Rp 1.725.737.000.000 sedangkan biaya sosial yang dialokasikan adalah sebesar $\mathrm{Rp} 1.982 .701 .000$ atau $0,11 \%$ dari total penjualan bersih. Pada tahun 2005, penjualan bersih perusahaan sebesar Rp 1.558.800.000.000 sedangkan biaya sosial yang dialokasikan sebesar Rp 1.423.807.000 atau 0,09\% dari total penjualan bersih. Pada tahun 2006, penjualan bersih perusahaan sebesar Rp 1.523.991.000.000 sedangkan biaya sosial yang dialokasikan sebesar Rp 1.899.793.000 atau 0,12\% dari total penjualan bersih. Dan pada tahun 2007 dimana penjualan bersih mengalami kenaikan yang cukup tajam menjadi sebesar Rp. 2.413.293.000.000 namun alokasi biaya sosialnya merupakan yang paling rendah dalam kurun waktu 5 tahun terakhir (periode 2003 sampai dengan 2007) yaitu hanya sebesar Rp. 1.194.112.000 atau sebesar $0,05 \%$ dari total penjualan bersih.

\section{Tabel 4.8}

\section{Perbandingan Kenaikan/(Penurunan) Penjualan Bersih terhadap Biaya Sosial}

(Dalam Ribuan Rupiah)

\begin{tabular}{|c|c|c|c|c|c|c|c|c|}
\hline & \multirow{2}{*}{$\begin{array}{l}\text { Penjualan } \\
\text { Bersih }\end{array}$} & \multirow{2}{*}{$\begin{array}{c}\text { Proporsi } \\
\text { Penj } \\
\text { Bersih }\end{array}$} & \multicolumn{2}{|c|}{ Kenaikan/(Penurunan) } & \multirow{2}{*}{$\begin{array}{l}\text { Biaya } \\
\text { Sosial }\end{array}$} & \multirow{2}{*}{$\begin{array}{l}\text { Proporsi } \\
\text { By Sosial }\end{array}$} & \multicolumn{2}{|c|}{ Kenaikan/(Penurunan) } \\
\hline & & & Nilai & $\%$ & & & Nilai & $\%$ \\
\hline $\begin{array}{l}\text { Tahun } \\
2003\end{array}$ & 1.481 .936 .000 & 17,03 & & & 2.822 .916 & 30,28 & & \\
\hline $\begin{array}{l}\text { Tahun } \\
2004 \\
\end{array}$ & 1.725 .737 .000 & 19,83 & 243.801 .000 & 2,80 & 1.982 .701 & 21,27 & $(840.215)$ & $(9,01)$ \\
\hline
\end{tabular}




\begin{tabular}{|c|c|c|c|c|c|c|c|c|}
\hline $\begin{array}{l}\text { Tahun } \\
2005\end{array}$ & 1.558 .800 .000 & 17,91 & $(166.937 .000)$ & $(1,92)$ & 1.423 .807 & 15,27 & $(558.894)$ & $(5,99)$ \\
\hline $\begin{array}{l}\text { Tahun } \\
2006\end{array}$ & 1.523 .991 .000 & 17,51 & $(34.809 .000)$ & $(0,40)$ & 1.899 .793 & 20,38 & 475.986 & 5,11 \\
\hline $\begin{array}{l}\text { Tahun } \\
2007\end{array}$ & 2.413.293.000 & 27,73 & 889.302 .000 & 10,22 & 1.194 .112 & 12,81 & $(705.681)$ & $(7,57)$ \\
\hline TOTAL & 8.703.757.000 & & & & 9.323.329 & 100,00 & & \\
\hline
\end{tabular}

Sumber: Data Internal Perusahaan yang telah diolah

Dalam tabel 4.8 dapat dilihat perbandingan prosentasi kenaikan/penurunan penjualan bersih dengan biaya sosial. Dimana penjualan bersih pada tahun 2004 mengalami kenaikan sebesar 2,80\% atau sebesar $\mathrm{Rp} 243.801 .000$ dari $\mathrm{Rp} 1.481 .936 .000 .000$ pada tahun 2003 menjadi $\mathrm{Rp}$ 1.725.737.000.000, namun di sisi lain untuk biaya sosialnya justru mengalami penurunan sebesar 9,01\% atau sebesar Rp 840.215.000 dari Rp 2.822.916.000 pada tahun 2003 menjadi Rp 1.982.701.000. Penjualan bersih pada tahun 2005 mengalami penurunan sebesar 1,92\% atau sebesar Rp 166.937.000.000 dan biaya sosialnya mengalami penurunan sebesar 5,99\% atau sebesar $\mathrm{Rp}$ 558.894.000. Sedangkan di tahun 2006, penjualan bersih mengalami penurunan sebesar $0,40 \%$ atau sebesar Rp 34.809.000.000 namun di sisi lain biaya sosial yang dialokasikan oleh perusahaan mengalami kenaikan sebesar 5,11\% atau sebesar Rp 475.986.000. Dan pada tahun 2007 dimana penjualan bersih mengalami kenaikan yang cukup signifikan dalam kurun waktu 5 tahun terakhir (periode 2003 s/d 2007), yaitu sebesar Rp 2.413.293.000.000 atau naik sekitar 10,22\% atau sebesar Rp 889.302.000.000 dibandingkan dengan tahun 2006, namun kenaikan penjualan bersih tersebut tidak diimbangi dengan biaya sosialnya. Terbukti dari hasil pengolahan data justru didapatkan hasil bahwa biaya sosial yang dialokasikan oleh PT. Perkebunan Nusantara V (Persero) pada tahun 2007 merupakan biaya sosial terendah selama kurun waktu 5 tahun terakhir (periode $2003 \mathrm{~s} / \mathrm{d}$ 2007) yaitu hanya sebesar Rp 1.194.112.000 atau mengalami penurunan sebesar 7,57\% atau Rp 705.681.000 dibandingkan dengan tahun 2006.

Tabel 4.9

Proporsi Biaya Sosial untuk Kontribusi kpd Masyarakat

\begin{tabular}{|c|c|c|c|c|}
\hline & \multirow{2}{*}{$\begin{array}{l}\text { Kontribusi } \\
\text { kpd Masy }\end{array}$} & \multirow{2}{*}{ Proporsi } & \multicolumn{2}{|c|}{ Kenaikan/(Penurunan) } \\
\hline & & & Nilai & Prosentase \\
\hline Tahun 2003 & 616.870 .000 & 13,10 & & \\
\hline Tahun 2004 & 1.582 .618 .000 & 33,62 & 965.748 .000 & 20,51 \\
\hline Tahun 2005 & 878.335 .000 & 18,66 & $(704.283 .000)$ & $(14,96)$ \\
\hline Tahun 2006 & 692.400 .000 & 14,71 & $(185.935 .000)$ & $(3,95)$ \\
\hline \multirow[t]{2}{*}{ Tahun 2007} & 937.484 .000 & 19,91 & 245.084 .000 & 5,21 \\
\hline & 4.707.707.000 & 100,00 & & \\
\hline
\end{tabular}

Sumber: Data Internal Perusahaan yang telah diolah

Proporsi biaya sosial untuk Kontribusi kepada masyarakat periode 2003 sampai dengan 2005 dilihat dari proporsinya juga bervariasi dimana pada tahun 2003 hanya sebesar 13,10\% atau sebesar Rp 616.870.000 namun di tahun 2004 terjadi peningkatan yang cukup signifikan dimana proporsi untuk kontribusi kepada masyarakat di tahun 2004 menjadi 33,62\% atau sebesar Rp 1.582.618.000 yaitu terjadi kenaikan sebesar 20,51\% atau sebesar Rp 965.748.000 dibandingkan tahun 2004. Sedangkan di tahun 2005 mengalami penurunan yang cukup signifikan dimana proporsi untuk kontribusi kepada masyarakat di tahun 2005 menjadi 18,66\% atau sebesar Rp 878.335.000 yaitu terjadi penurunan sebesar 14,96\% atau sebesar Rp 704.283.000. Pada tahun 2006 kembali terjadi penurunan dimana proporsi untuk kontribusi kepada masyarakat di tahun 2006 menjadi 14,71\% atau sebesar Rp 692.400.000 yaitu terjadi penurunan sebesar 3,95\% atau sebesar Rp 185.935.000. Dan terakhir pada tahun 2007 kontribusi kepada masyarakat mengalami kenaikan dengan proporsi kontribusi kepada 
masyarakat sebesar 19,91\% atau sebesar Rp 937.484.000 dilihat dari jumlahnya mengalami kenaikan sebesar 5,21\% atau sebesar Rp 245.084.000.

Terjadinya kenaikan maupun penurunan biaya sosial untuk kontribusi kepada masyarakat disebabkan oleh kontribusi yang diberikan perusahaan kepada Rukun Tetangga (RT), Rukun Warga (RW) dan instansi pemerintah seperti kelurahan dan kecamatan serta instansi militer (KODIM, KORAMIL dan Kepolisian) setempat tidak dipengaruhi oleh banyaknya produksi, melainkan jika permohonan untuk menjadi sponsor dalam berbagai kegiatan yang ada di lingkungan sekitar bertambah maka manajemen mengambil kebijakan menambah alokasi biaya sponsorship. Kenaikan alokasi biaya sosial kepada masyarakat tersebut signifikan terhadap kenaikan biaya sosial perusahaan yang dibebankan oleh perusahaan. Sedangkan untuk alokasi biaya sosial terhadap lingkungan hidup akan dijelaskan pada tabel 4.10 berikut :

Tabel 4.10

Proporsi Biaya Sosial untuk Kontribusi kpd Lingkungan Hidup

\begin{tabular}{|c|c|c|c|c|}
\hline & \multirow{2}{*}{$\begin{array}{c}\text { Kontribusi kpd } \\
\text { Lingkungan Hidup }\end{array}$} & \multirow{2}{*}{ Proporsi } & \multicolumn{2}{|c|}{ Kenaikan/(Penurunan) } \\
\hline & & & Nilai & Prosentase \\
\hline Tahun 2003 & 2.197 .029 .000 & 58,35 & & \\
\hline Tahun 2004 & 241.335 .000 & 6,41 & $(1.955 .694 .000)$ & $(51,94)$ \\
\hline Tahun 2005 & 351.549 .000 & 9,34 & 110.214 .000 & 2,93 \\
\hline Tahun 2006 & 975.415 .000 & 25,91 & 623.866 .000 & 16,57 \\
\hline Tahun 2007 & - & _ & - & $(25,91)$ \\
\hline & 3.765.328.000 & 100,00 & & \\
\hline
\end{tabular}

Sumber: Data Internal Perusahaan yang telah diolah

Proporsi biaya sosial untuk kontribusi kepada lingkungan hidup selama periode 2003 sampai dengan 2007 nilainya bervariasi. Pada tahun 2003, kontribusi kepada lingkungan hidup senilai Rp 2.197.029.000 atau dengan nilai proporsi 58,35\%. Pada tahun 2004, kontribusi untuk lingkungan hidup mengalami penurunan yang cukup signifikan yaitu sebesar Rp 1.955.694.000 atau sekitar 51,94\%, dimana jumlah kontribusi untuk lingkungan hidup sebesar Rp 241.335 .000 atau hanya sebesar 6,41\%. Pada tahun 2005 terjadi sedikit kenaikan yaitu sebesar Rp 110.214.000 atau 2,93\% dimana total kontribusi yang diberikan untuk lingkungan hidup tahun 2005 adalah sebesar Rp 351.549.000. Kemudian terus mengalami kenaikan, di tahun 2006 total kontribusi kepada lingkungan hidup menjadi sekitar Rp 975.415.00 atau sebesar 25,91\%, jika dilihat dari prosentase kenaikan pada tahun 2006 terjadi kenaikan sebesar 16,57\% atau sekitar Rp 623.866.000 dibandingkan tahun 2005. Namun pada tahun 2007, perusahaan tidak mengalokasikan dana untuk lingkungan hidup. Sedangkan untuk proporsi biaya sosial kepada sumber daya manusia akan dijelaskan dalam tabel 4.11 berikut ini :

Tabel 4.11

Proporsi Biaya Sosial untuk Kontribusi kpd Sumber Daya Manusia

\begin{tabular}{|l|r|r|r|r|}
\hline & \multirow{2}{*}{$\begin{array}{c}\text { Kontribusi kpd } \\
\text { Sumber Daya } \\
\text { Manusia }\end{array}$} & \multirow{2}{*}{ Proporsi } & \multicolumn{2}{|c|}{ Kenaikan/(Penurunan) } \\
\cline { 5 - 5 } & 9.017 .000 & 1,06 & & Nilai \\
Tahun 2003 & 158.748 .000 & 18,67 & 149.731 .000 & 17,61 \\
\hline Tahun 2004 & 193.923 .000 & 22,81 & 35.175 .000 & 4,14 \\
\hline Tahun 2005 & 231.978 .000 & 27,28 & 38.055 .000 & 4,48 \\
\hline Tahun 2006 & 256.628 .000 & 30,18 & 24.650 .000 & 2,90 \\
\hline Tahun 2007 & $\mathbf{8 5 0 . 2 9 4 . 0 0 0}$ & $\mathbf{1 0 0 , 0 0}$ & & \\
\hline & & & & \\
\hline
\end{tabular}

Sumber: Data Internal Perusahaan yang telah diolah 
Pada proporsi biaya sosial untuk kontribusi kepada sumber daya manusia selama periode 2003 sampai dengan tahun 2007 terus mengalami peningkatan dari tahun ke tahun. Dimana pada tahun 2003, total kontribusi kepada sumber daya manusia hanya sebesar Rp 9.017.000 atau 1,06\%. Kemudian pada tahun 2004 terjadi peningkatan yang cukup signifikan yaitu meningkat sekitar 17,61\% atau sebesar Rp 149.731.000 sehingga total kontribusi kepada sumber daya manusia tahun 2004 menjadi sebesar Rp 158.748.000 atau dengan jumlah proporsi sekitar 18,67\%. Pada tahun 2005 total kontribusi kepada sumber daya manusia kembali mengalami peningkatan menjadi sebesar $\mathrm{Rp}$ 193.923.000 atau dengan jumlah proporsi sekitar 22,81\% dibandingkan dengan tahun lalu meningkat sebesar 4,14\% atau sebesar Rp 35.175.000. Pada tahun 2006 juga terjadi peningkatan sekitar 4,48\% atau sebesar Rp 38.055.000 sehingga total kontribusi kepada sumber daya manusia tahun 2006 adalah sebesar Rp 231.978.000 atau dengan jumlah proporsi sekitar 27,28\%. Dan pada akhir tahun 2007 walaupun tidak terlalu besar namun tetap terjadi peningkatan dibandingkan tahun 2006, yaitu seitar 2,90\% atau sebesar Rp 24.650.000 dimana total kontribusi kepada sumber daya manusia pada tahun 2007 sebesar Rp 256.628.000 atau dengan jumlah proporsi sekitar 30,18\% .Hal ini sangatlah wajar, mengingat PT. Perkebunan Nusantara V (Persero) merupakan perusahaan yang bersifat Labour Insentif sehingga biaya tenaga kerja memiliki jumlah yang besar dalam struktur biayanya. Sedangkan untuk proporsi biaya sosial terhadap pendapatan dapat dilihat pada tabel 4.12 berikut:

\section{Tabel 4.12}

Proporsi Biaya Sosial terhadap Pendapatan Usaha

(Dalam Ribuan Rupiah)

\begin{tabular}{|l|r|r|r|r|r|}
\hline & & & & \\
\multicolumn{1}{|c|}{ Uraian } & \multicolumn{1}{c|}{2003} & \multicolumn{1}{c|}{2004} & \multicolumn{1}{c|}{2005} & \multicolumn{1}{c|}{2006} & \multicolumn{1}{c|}{2007} \\
\hline Pendapatan Usaha & 1.461 .935 .611 & 1.725 .736 .844 & 1.558 .898 .576 & 1.523 .991 .423 & 2.413 .293 .334 \\
\hline Biaya Sosial & 2.822 .916 & 1.982 .701 & 1.423 .807 & 1.899 .793 & 1.194 .112 \\
\hline Proporsi (\%) & $\mathbf{0 , 1 9}$ & $\mathbf{0 , 1 1}$ & $\mathbf{0 , 0 9}$ & $\mathbf{0 , 1 2}$ & $\mathbf{0 , 0 5}$ \\
\hline
\end{tabular}

Sumber: Data Internal Perusahaan yang telah diolah

Berdasarkan tabel 4.12 di atas, nilai proporsi biaya sosial terhadap pendapatan usaha memiliki nilai yang sama dengan proporsi biaya sosial terhadap penjualan bersih. Dimana pada tahun 2003, pendapatan usaha PT. Perkebunan Nusantara V (Persero) sebesar Rp 1.461.935.611.000 sedangkan untuk biaya sosial yang dikeluarkan oleh perusahaan sekitar 0,19\% atau sebesar Rp 2.822.916.000. Pada tahun 2004, biaya sosial yang dikeluarkan mulai mengalami penurunan dibandingkan tahun 2003 yaitu hanya sebesar $\mathrm{Rp} 1.982 .701 .000$ atau $0,11 \%$ dari total pendapatan usaha sebesar $\mathrm{Rp}$ 1.725.736.844.000 Pada tahun 2005, pendapatan usaha menurun dibandingkan dengan tahun 2004 yaitu hanya sebesar Rp 1.558.898.576.000 sehungga biaya sosial yang dikeluarkan oleh perusahaan juga mengalami penurunan dibandingkan dengan tahun 2004 yaitu hanya sebesar $0,09 \%$ dari total pendapatan usaha atau sekitar Rp 1.423.807.000. Sedangkan pada tahun 2006 dimana pendapatan usaha perusahaan kembali mengalami penurunan dibandingkan tahun 2005 yaitu hanya sekitar Rp 1.523.991.423.000 namun untuk biaya sosialnya justru mengalami kenaikan sebesar $0,12 \%$ dari total pendapatan usaha atau sekitar Rp 1.899.793.000. Namun pada tahun 2007, dimana pendapatan usaha meningkat drastis ternyata tidak diikuti dengan peningkatan biaya sosial. Hal ini terbukti dengan rendahnya nilai biaya sosial yang dialokasikan oleh perusahaan yaitu hanya sekitar $0,05 \%$ atau sebesar Rp 1.194.112.000. Padahal total pendapatan usaha PT. Perkebunan Nusantara V (Persero) pada tahun 2007 merupakan yang paling tinggi dalam kurun waktu 5 tahun terakhir (periode $2003 \mathrm{~s} / \mathrm{d}$ 2007) yaitu sebesar Rp 2.413.293.334. Rendahnya biaya sosial yang dikeluarkan oleh perusahaan adalah karena perusahaan tidak mengalokasikan biaya sosial untuk lingkungan hidup. Dimana jika dilihat pada tabel 4.5 mengenai laporan biaya sosial PTPN V (persero), perusahaan tidak mengalokasikan dana untuk infrastruktur, olahraga, kesenian maupun bencana alam. Padahal di tahun-tahun sebelumnya perusahaan selalu mengalokasikan dana untuk lingkungan hidup dengan nilai proporsi yang cukup besar . 
Kurangnya alokasi dana untuk biaya sosial tersebut dikarenakan tidak adanya aturan baku dari pemerintah mengenai besarnya biaya sosial yang harus dikeluarkan oleh perusahaan. Sehingga sampai saat ini, untuk biaya sosial yang dikeluarkan oleh perusahaan tergantung dari kebijakan pihak manajemen PT. Perkebunan Nusantara V (Persero).

\section{KESIMPULAN DAN SARAN \\ 5.1 Kesimpulan}

Dari uraian di atas, maka penulis dapat mengambil kesimpulan terhadap perilaku sosial PT.

Perkebunan Nusantara V (Persero) terhadap lingkungan sekitarnya. Kesimpulan itu antara lain adalah :

1. PT. Perkebunan Nusantara V (Persero) telah melakukan beberapa bentuk pertanggungjawaban sosial perusahaan terhadap lingkungan sekitar, yaitu antara lain perusahaan telah menyalurkan dana bina lingkungan yang meliputi sektor Pendidikan, sektor Kerohanian, sektor Kesehatan, sektor Olahraga, sektor Kesenian, bantuan untuk Bencana Alam dan Infrastruktur.

2. Dalam hal laporan CSR, PT. Perkebunan Nusantara V (Persero) telah melaporkan biaya sosial yang dikeluarkan oleh perusahaan untuk menunjang aktifitas pertanggungjawaban sosial perusahaan. Berdasarkan pengamatan terhadap biaya-biaya yang dikeluarkan perusahaan maka elemen-elemen yang terkandung didalam laporan biaya sosial dapat dibagi menjadi 3 bagian, yaitu: Kontribusi kepada Masyarakat, Kontribusi kepaa Lingkungan Hidup dan Kontribusi kepada Sumber Daya Manusia.

3. Tingkat penjualan bersih perusahaan tidak mempengaruhi besarnya biaya sosial yang dikeluarkan oleh perusahaan. Hal ini terbukti dari hasil analisis yang dilakukan selama 5 tahun terakhir (periode $2003 \mathrm{~s} / \mathrm{d}$ 2007) dimana hasil yang didapatkan bervariasi yaitu, pada tahun 2003 penjualan bersih perusahaan sebesar Rp. 1.481.936.000.000 sedangkan biaya sosial yang dialokasikan adalah sebesar Rp. 2.822.916 000 atau $0,19 \%$ dari total penjualan bersih. Pada tahun 2004, penjualan bersih sebesar Rp 1.725.737.000.000 sedangkan biaya sosial yang dialokasikan adalah sebesar Rp 1.982.701.000 atau $0,11 \%$ dari total penjualan bersih. Pada tahun 2005, penjualan bersih perusahaan sebesar Rp 1.558.800.000.000 sedangkan biaya sosial yang dialokasikan sebesar Rp 1.423.807.000 atau 0,09\% dari total penjualan bersih. Pada tahun 2006, penjualan bersih perusahaan sebesar Rp 1.523.991.000.000 sedangkan biaya sosial yang dialokasikan sebesar Rp 1.899.793.000 atau $0,12 \%$ dari total penjualan bersih. Dan pada tahun 2007 dimana penjualan bersih mengalami kenaikan yang cukup tajam menjadi sebesar Rp. 2.413.293.000.000 namun alokasi biaya sosialnya merupakan yang paling rendah dalam kurun waktu 5 tahun terakhir (periode 2003 sampai dengan 2007) yaitu hanya sebesar Rp. 1.194.112.000 atau sebesar $0,05 \%$ dari total penjualan bersih.

4. PT. Perkebunan Nusantara V (Persero) telah melakukan aktivitas yang berkaitan dengan kontribusi terhadap produk dan jasa dimana, PT. Perkebunan Nusantara V (Persero) telah melakukan penelitian dan pengembangan produk dan jasa ini terkait dengan keamanan dan kenyamanan konsumen sebagai pengguna produk dan jasa yang dihasilkan oleh perusahaan. Selain itu riset pasar juga gencar dilakukan agar perusahaan dapat melakukan pemetaan terhadap pasar yang membutuhkan produk dan jasa yang dihasilkan oleh perusahaan. Namun belum ada alokasi biaya sosial yang diberikan oleh PT. Perkebunan Nusantara V (Persero). Hal ini terlihat dari laporan biaya sosial yang ada, dimana PT. Perkebunan Nusantara V (Persero) tidak mengalokasikan biaya untuk produk dan jasa.

5. Pihak manajemen dalam hal komitmen untuk mensejahterakan karyawan telah mempunyai komitmen yang jelas, hal ini dibuktikan dengan kebijakan-kebijakan yang telah dikeluarkan oleh perusahaan terkait dengan kesejahteraan karyawan.

\subsection{Saran}

Secara umum, saran yang bisa diberikan oleh penulis adalah : 
1. Kepada Pihak Perusahaan

Perlu dialokasikan biaya sosial untuk kontribusi terhadap produk dan jasa, karena produk dan jasa yang dihasilkan oleh perusahaan tidak mungkin 100\% tanpa cacat, walaupun telah melalui proses standardisasi mutu. Kontribusi terhadap produk dan jasa ini bisa dilakukan dalam bentuk mengasuransikan produk yang dihasilkan oleh perusahaan atau mengasuransikan pengguna dari produk perusahaan. Sehingga konsumen akan merasa nyaman dan aman jika memakai produk yang dihasilkan. Walaupun belum ada standard yang jelas terhadap biaya sosial ini, dapat dijadikan pertimbangan pengalokasian biaya sosial untuk kontibusi terhadap produk dan jasa.

2. Kepada Pihak Pemerintah

Disarankan untuk segera membuat aturan yang berisi tentang format baku laporan biaya sosial perusahaan sebagai bentuk tanggung jawab sosial perusahaan terhadap lingkungannya baik itu bentuk laporannya maupun besarnya proporsi biaya sosial tersebut terhadap penjualan atau laba bersih perusahaan. Sehingga pemerintah mempunyai tolok ukur yang jelas terhadap perusahaan - perusahaan yang mempunyai atau tidak mempunyai tanggung jawab sosial pada lingkungan sekitarnya dan terhadap perusahaan yang tidak memenuhi aturan tersebut bisa dikenakan sanksi baik administratif ataupun sanksi hukum.

\section{DAFTAR PUSTAKA}

Anggraini, Fr.Reni Retno, Pengungkapan Informasi Sosial dan Faktor-Faktor yang Mempengaruhi Pengungkapan Informasi Sosial dalam Laporan Keuangan Tahunan (Studi Empiris pada Perusahaan-Perusahaan yang terdaftar Bursa Efek Jakarta), Simposium Nasional Akuntansi IX, Padang. 2006

Alam, Solihin Makmur. Value Added Statement : Salah Satu Wujud Pertanggungjawaban Perusahaan Kepada Stakeholders. Media Akuntansi. No.34 (Juni-Juli). 2003

Belkaoui, Ahmed R. Accounting Theory. Fourth Edition. Ilinois : Business Press. 2000

Gazdar, Kaevan. Reporting Nonfinancials. Jhon Wiley and Sons. Ltd. 2007

Glautier, MWE., B, Underdown. Accounting Theory and Practice. Seventh Edition. Prentice Hall International. 2001

Harahap, Sofyan Syafri. 2002. Teori Akuntansi. Jakarta : PT. Raja Grafindo Persada. 2002

, Teori Akuntansi. Edisi Revisi. Jakarta : PT. Raja Grafindo Persada. 2003

Hopkins, Michael. Corporate Social Responsibility and International Development Is Business the Solution?. Earthscan. 2007

Jorgensen, Bjorn N. and Michael T. Kischenheiter. Discretionary Risk Disclosure. The Accounting Review. Vol. 78, No. 2, p. 449-469. 2003

Komar, Seful. Akuntansi Pertanggungjawaban Sosial (Social Responsibility Accounting) dan Korelasinya dengan Akuntansi Islam. Media Akuntansi. Edisi 42/Tahun XI, hal. 54-58. 2004

Owen, David. CSR After Enron: A Role for the Academic Accounting Profession?. Working Paper. Sosial Science Research Network. 2005 
Simanjuntak, Binsar H. dan Lusi Widiastuti. Faktor-faktor yang Mempengaruhi Kelengkapan Pengungkapan Laporan Keuangan pada Perusahaan Manufaktur yang terdaftar di Bursa Efek Jakarta. Jurnal Riset Akuntansi Indonesia. Vol. 7, No. 3, September, hal. 251-366. 2004

Suharto, Harry. Standar Akuntansi Lingkungan: Kebutuhan Mendesak. Media Akuntansi. Edisi 42/Tahun XI, hal. 4-5. 2004

The Association of Chartered Certified Accountants (ACCA). An Introduction to Sustainability Reporting for Organisations in Indonesia. 2004

Waddock, Sandra dan Charles, Bodwell. Total Responsibility Management: The Manual. Greenleaf Publishing. 2007

Wibisono, Yusuf. Membedah Konsep dan Aplikasi Corporate Social Responsibility. Fascho Publishing, Gresik. 2007

Yakovleva, Natalia. Corporate Social Responsibility in the Mining Industry. Ashgate Publishing Limited. 2005 